\title{
REVIEW
}

\section{Regulation of Pancreatic $\beta$-cell Function by the HNF Transcription Network: Lessons from Maturity-Onset Diabetes of the Young (MODY)}

\author{
KAZUYA YAMAGATA \\ Department of Internal Medicine and Molecular Science, Graduate School of Medicine, Osaka University, Osaka 565-0871, Japan
}

\section{Introduction}

TYPE 2 diabetes mellitus is a heterogenous group of disorders characterized by a high blood glucose level. Pancreatic $\beta$-cell dysfunction and insulin resistance of target tissues play a central role in the pathogenesis of diabetes. Although multiple genetic and environmental factors (e.g., physical inactivity and overnutrition) may contribute to the development of type 2 diabetes, about $2-5 \%$ of these patients suffer from a monogenic disease with autosomal dominant inheritance. This monogenic form of type 2 diabetes is called maturityonset diabetes of the young (MODY). MODY is a clinically heterogenous disorder, which is characterized by autosomal dominance, an early age of onset, and a primary defect of pancreatic $\beta$-cell function. In 1996 , we showed that heterozygous mutations in genes encoding hepatocyte nuclear factor (HNF)- $1 \alpha$ and HNF- $4 \alpha$ cause MODY 3 and MODY1, respectively [1, 2]. HNF- $1 \alpha$ and HNF- $4 \alpha$ are functionally related transcription factors, and $\mathrm{HNF}-4 \alpha$ regulates the transcription of HNF-1 $\alpha$. Further studies of MODY patients have identified defects of three other genes encoding transcription factors: HNF-1 $\beta$ (MODY5) [3], insulin promoter factor-1 (IPF-1)/pancreatic duodenal homeobox 1 (PDX-1) (MODY4) [4], and neurogenic differentiation $1 / \beta$-cell E-box transactivation 2 (NeuroD1/BETA2) (MODY6) [5] (Table 1). All five transcription factors that have been shown to have a role in MODY are expressed in pancreatic $\beta$ -

Correspondence to: Dr. Kazuya YAMAGATA, Department of Internal Medicine and Molecular Science, Graduate School of Medicine, B5, Osaka University, 2-2 Yamada-oka, Suita, Osaka 565-0871, Japan cells and regulate the expression of insulin as well as other proteins involved in glucose metabolism and/or $\beta$-cell development. These findings suggest the importance of transcription factor for normal $\beta$-cell function and have led to the concept of "diabetes mellitus as a disorder of abnormal transcription factors". In addition, identification of mutations of the three HNF genes in diabetic patients with impaired insulin secretion has indicated the important role of HNF transcription factors in the normal regulation of insulin secretion. As shown by the term of "hepatocyte nuclear factor", the critical role of these factors in pancreatic $\beta$-cells had not been recognized before cloning of the MODY genes. Studies of HNF-related diabetes may give us some important clues towards better understanding of the mechanism of insulin secretion. In this review, I focus on the significance of HNFs with respect to glucose metabolism.

\section{HNF-1 $\alpha$ diabetes}

HNF-1 $\alpha$ was initially identified as a transcription factor that was enriched in the liver, but its gene is also expressed in the pancreas, stomach, small intestine, and kidney. Both endocrine cells (glucagon-positive, insulin-positive, somatostatin-positive, and pancreatic polypeptide (PP) cells) and exocrine cells in the pancreas express HNF-1 $\alpha$ from the developmental stage [6]. HNF-1 $\alpha$ is composed of three functional domains: an amino-terminal dimerization domain, a DNA-binding domain with homeodomain-like and POU-like motifs, and a $\mathrm{COOH}$-terminal transactivation domain. HNF-1 $\alpha$ binds DNA as a homodimer or as a heterodimer with HNF-1 $\beta$.

Mutations associated with diabetes have been found 
Table 1. Comparison of the different types of MODY

\begin{tabular}{|c|c|c|c|c|c|c|}
\hline & MODY1 & MODY2 & MODY3 & MODY4 & MODY5 & MODY6 \\
\hline Gene & HNF- $4 \alpha$ & glucokinase & HNF-1 $\alpha$ & IPF-1 & HNF-1 $\beta$ & NeuroD1 \\
\hline Chromosomal location & $20 \mathrm{q} 12-13.1$ & $7 \mathrm{p} 15-13$ & $12 q 24$ & $13 \mathrm{q} 12.1$ & $17 \mathrm{q}$ & $2 q 32$ \\
\hline Frequency & rare & $\begin{array}{l}\text { relatively } \\
\text { common } \\
\text { (rare in Japan) }\end{array}$ & most common & rare & rare & rare \\
\hline Severity of hyperglycemia & severe & mild & severe & mild $\sim$ severe & mild $\sim$ severe & mild $\sim$ severe \\
\hline Clinical features & $\begin{array}{l}\text { diabetes with } \\
\text { impaired insulin } \\
\text { secretion }\end{array}$ & $\begin{array}{l}\text { mild } \\
\text { hyperglycemia } \\
\text { with minor } \\
\text { deterioration } \\
\text { with age }\end{array}$ & $\begin{array}{l}\text { diabetes with } \\
\text { impaired insulin } \\
\text { secretion }\end{array}$ & $\begin{array}{l}\text { diabetes with } \\
\text { impaired insulin } \\
\text { secretion }\end{array}$ & $\begin{array}{l}\text { diabetes and } \\
\text { progressive } \\
\text { renal } \\
\text { dysfunction }\end{array}$ & $\begin{array}{l}\text { diabetes with } \\
\text { impaired insulin } \\
\text { secretion }\end{array}$ \\
\hline
\end{tabular}

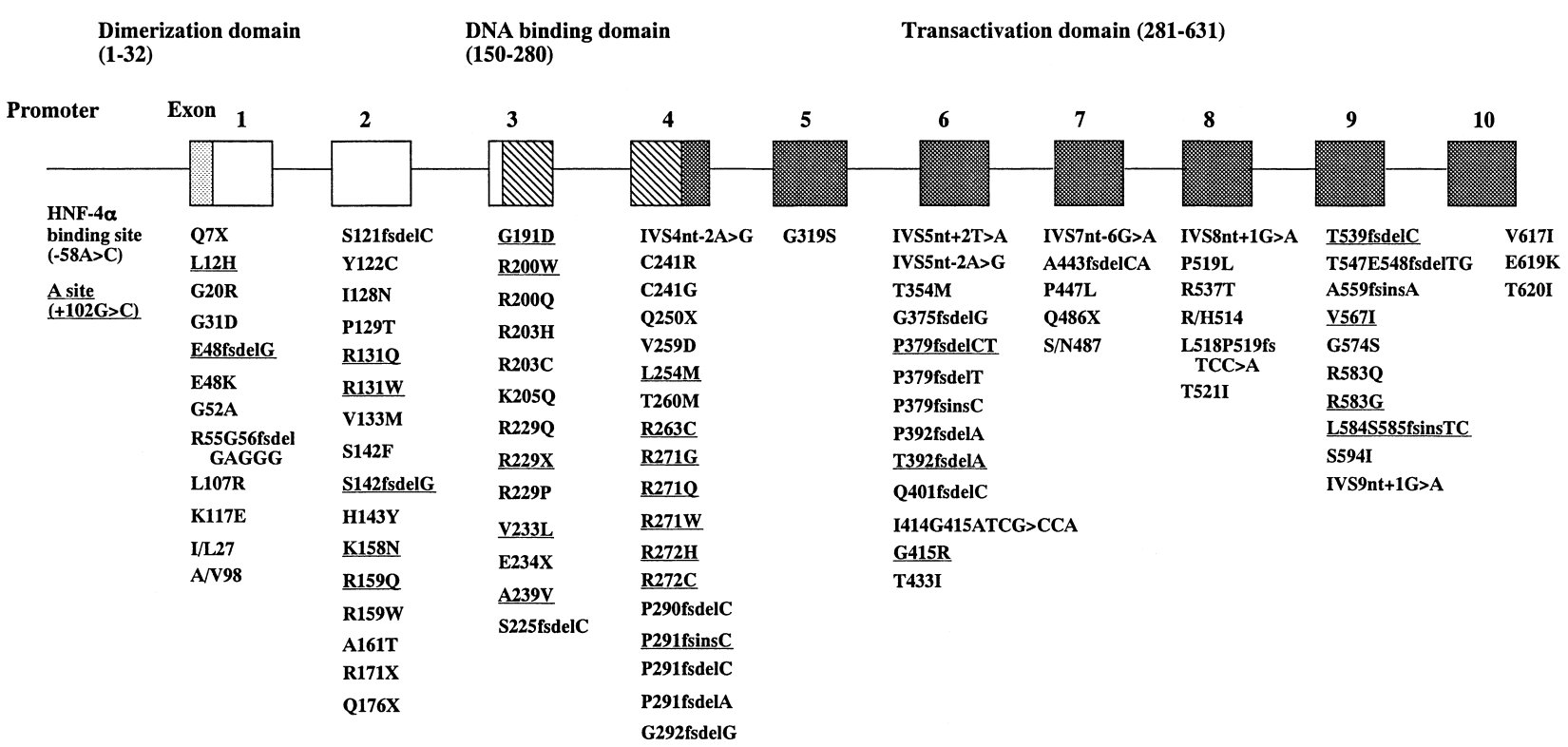

Fig. 1. Mutations and polymorphisms in the HNF-1 $\alpha$ gene. Mutations found in Japanese subjects with diabetes are underlined.

in all regions of the HNF-1 $\alpha$ gene, including the promoter. Mutation screening of the HNF-1 $\alpha$ gene in different racial groups of MODY patients has shown that defects of this gene are a common cause of MODY in the UK (73\%), France (25\%), and Japan $(10-15 \%)$ [7]. More than 90 distinct mutations of the HNF-1 $\alpha$ gene have been reported so far, and the mutations and polymorphisms reported for this gene are shown in Fig. 1. The most common mutation of the HNF- $1 \alpha$ gene is insertion of $\mathrm{C}$ in the poly $\mathrm{C}$ tract around codon 291 (P291fsinsC) and this mutation is considered to be due to slipped mispairing during DNA replication rather than a founder effect. This mutation is especially common in Caucasians. In Japanese, codons 271 and 272 may be vulnerable sites.
The chief clinical characteristic of HNF- $1 \alpha$ diabetes is impaired insulin secretion by pancreatic $\beta$-cells $[8$, 9]. Mutation of the glucokinase gene also causes MODY associated with primary $\beta$-cell dysfunction [10]. In the case of glucokinase mutations, patients usually show mild hyperglycemia throughout life. In contrast, patients with HNF-1 $\alpha$ diabetes show rapid deterioration of glycemia with age and most of them soon need treatment with oral hypoglycemic drugs or insulin [7]. In keeping with the rapid worsening of their glucose levels, subjects with HNF-1 $\alpha$ mutations sometimes have severe diabetic microangiopathy. Insulin resistance is an important clinical feature of common type 2 diabetes. It has been reported, however, that insulin sensitivity is actually increased in 
HNF-1 $\alpha$ diabetes [7].

Mutations of the HNF-1 $\alpha$ gene may cause diabetes through haploinsufficiency (simple loss of function) or by a dominant negative mechanism. We found that P291fsinsC-HNF-1 $\alpha$ has a dominant negative effect, but most HNF-1 $\alpha$ defects are due to simple loss-offunction mutations [11-13]. Since one allele of the HNF- $1 \alpha$ gene is normal in these patients, the level of HNF- $1 \alpha$ expression must play a critical role in determining $\beta$-cell function. We identified a mutation at the A site of the promoter region in a diabetic family and found that this mutation was associated with an increase of promoter activity. Thus, appropriate level of HNF-1 $\alpha$ activity might be important for normal $\beta$-cell function.

Although mutations of the HNF- $1 \alpha$ gene were originally identified in subjects with a clinical diagnosis of MODY, some mutations have been found in patients with a clinical diagnosis of type 1 diabetes, since the clinical features of severe HNF- $1 \alpha$ diabetes are similar to those of type 1 diabetes $[12,14]$. Interestingly, mutations of the HNF-1 $\alpha$ gene have also been identified in subjects with typical type 2 diabetes. G319S is a missense mutation of the transactivation domain that reduces transactivation activity by nearly $50 \%$. This mutation is found in about $40 \%$ of Canadian Oji-Cree Indians with type 2 diabetes. The mutation is strongly associated with type 2 diabetes in this population and has a very high specificity for predicting the onset of type 2 diabetes [15]. G191D, L254M, and R583Q mutations of the HNF-1 $\alpha$ gene have also been identified in a small number of patients with late-onset type 2 diabetes [16-18]. Our in vitro studies showed that G191D is a weak loss-of-function mutation in HeLa cells, but has almost normal transactivation activity in $\beta$-cell-like MIN6 cells [13]. Mild HNF-1 $\alpha$ mutations may contribute to the polygenic background and predispose some persons to type 2 diabetes. Mild mutations of the IPF-1/MODY4 gene also cause a predisposition to type 2 diabetes [19, 20].

\section{Targets of HNF-1 $\alpha$ in glucose metabolism}

HNF- $1 \alpha$ is critical for normal $\beta$-cell function, but its actual role in $\beta$-cells is not yet clear. Several targets of HNF-1 $\alpha$ have been identified through various approaches. Glucose transporter type 2 (GLUT2) facilitates glucose transport in $\beta$-cells and
L-type pyruvate kinase (PKL) is a rate-limiting enzyme of glycolysis that is expressed in $\beta$-cells. HNF$1 \alpha$ can activate both the GLUT2 gene and the PKL gene by binding to their promoter sequences [21, 22]. HNF-1 $\alpha$ also transactivates the transcription of the aldolase B gene as an enhancer. The insulin gene may be an endogenous target of HNF-1 $\alpha$ in rats [21]. However, the ability of HNF- $1 \alpha$ to bind to the insulin gene in humans appears to be weaker [23] compared with its binding to the rat insulin gene. HNF-1 $\alpha$ also regulates the expression of the mitochondrial 2-oxoglutarate dehydrogenase (OGDH) E1 subunit gene [24]. In addition to genes involved in glucose transport, glycolysis, and mitochondrial metabolism, HNF-1 $\alpha$ can influence the expression of genes such as IGF-1, cyclin E, p27KIP1, and Bcl-xL, which regulate cell proliferation and apoptosis $[25,26]$. A reduction of $\beta$-cell numbers and a decrease of the $\beta$-cell proliferation rate has been reported in HNF-1 $\alpha$ knockout mice as well as in transgenic mice overexpressing dominant negative P291fsinsC-HNF-1 $\alpha$ in pancreatic $\beta$-cells $[22,27]$. It is well known that HNF- $4 \alpha$ regulates the transcription of HNF-1 $\alpha$ in hepatocytes, but HNF- $1 \alpha$ conversely transactivates the expression of HNF- $4 \alpha$ in the pancreas, indicating that HNF- $4 \alpha$ is an important target of HNF-1 $\alpha$ in $\beta$-cells [28]. The HNF- $3 \gamma$ and HNF- $4 \gamma$ genes are also targets of HNF- $1 \alpha$ [28]. HNF-1 $\alpha$ can bind to the regulatory element of the IPF-1/PDX-1 (MODY4) gene and activate its transcription in vitro, but little or no change of IPF-1/ PDX-1 gene expression was found in the $\beta$-cells of HNF- $1 \alpha$-inactivated mice $[6,29]$. In mice, HNF- $1 \alpha$ expression is seen in most pancreatic epithelial cells on embryonic day 10.5 and such early expression suggests a role of HNF-1 $\alpha$ in the development of the pancreas [6]. Indeed, the pancreatic islets of HNF-1 $\alpha$ knockout mice and transgenic mice expressing dominant negative HNF-1 $1 \alpha$ were found to be small and irregular in shape. HNF-1 $\alpha$ appears to be involved in the organization of pancreatic islets by regulating the expression of E-cadherin, which is an adhesion molecule critical for cell-cell adhesion within the islets [22]. Thus, HNF-1 $\alpha$ seems to have multiple roles in pancreatic $\beta$-cells.

\section{HNF-4 $\alpha$ diabetes}

HNF- $4 \alpha$ is a member of the steroid hormone re- 
ceptor superfamily and is expressed in the liver, pancreatic islets, kidney, and small intestine. It binds to DNA as a homodimer and activates the transcription of various target genes. HNF- $4 \alpha$ consists of several functional domains: an $\mathrm{N}$-terminal transactivation domain (AF-1), a DNA-binding domain, and a functionally complex C-terminal region that forms a ligand-binding domain, a dimerization interface, and a transactivation domain (AF-2). Recent crystal structure studies have suggested that fatty acids are endogenous ligands for HNF-4 $\alpha$ [30, 31].

HNF- $4 \alpha$ diabetes is relatively uncommon, although 20 possible mutations have been identified to date (Fig. 2). In the case of HNF-1 $\alpha$, some mutations are dominant negative, but all of the HNF- $4 \alpha$ mutations identified so far have been simple loss-of-function mutations. The HNF- $4 \alpha$ gene has two distinct promoters (P1 and P2). Hepatocytes utilize the proximal $\mathrm{P} 1$ promoter, but the recently identified distal P2 promoter is specially utilized in pancreatic $\beta$-cells [29, 32]. Exon $1 \mathrm{~A}$ is transcribed from the $\mathrm{P} 1$ promoter in the liver, but exon 1D is transcribed from the P2 promoter in pancreatic tissues. Using these two promoter systems, at least nine distinct isoforms are generated (HNF-4 $\alpha 1$ to HNF-4 $\alpha 9$ ). Pancreatic $\beta$-cells contain three isoforms, which are HNF-4 $\alpha 7$ (corresponding to $4 \alpha 1$ in the liver), HNF-4 $\alpha 8$ (corresponding to $4 \alpha 2$ ), and HNF- $4 \alpha 9$ (corresponding to $4 \alpha 3$ ) [33]. The P2 promoter includes both an IPF-1-binding site and a HNF-1-binding site. Interestingly, mutations of these binding sites (HNF-1 $\alpha$; $-181 \mathrm{G}$ to A, and IPF-1; -146T to $C)$ in the $\mathrm{P} 2$ promoter cause MODY $[32,33]$. In addition, hepatic expression of HNF- $4 \alpha$ mRNA was normal in HNF-1 $\alpha$ knockout mice, but its expression was abolished in the pancreas [28]. These results suggest the importance of the $\mathrm{P} 2$ promoter system for transcription of the HNF- $4 \alpha$ gene in pancreatic $\beta$-cells. However, a genetic study has identified a mutation in the HNF-4 $\alpha$-binding site of the promoter region of HNF- $1 \alpha$ in an Italian MODY family (-58A to $C$ ), indicating that HNF-4 $\alpha$-dependent transcription of HNF- $1 \alpha$ is also required for normal pancreatic $\beta$-cell function [34]. Taken together, these findings indicate the existence of a positive feedback circuit involving HNF- $1 \alpha$ and HNF- $4 \alpha$.

As suggested by the existence of cross-regulation between HNF- $1 \alpha$ and HNF- $4 \alpha$, the clinical features of HNF- $4 \alpha$ diabetes are similar to those of HNF-1 $\alpha$ diabetes. Most patients show progressive deterioration of glycaemic control but some subjects remain well controlled on diet alone or oral hypoglycemic agents. In HNF- $4 \alpha$ diabetic subjects, the onset of diabetes is also due to a primary defect of $\beta$-cell function. In addition, HNF- $4 \alpha$ is known to play an important role in regulating the expression of various proteins involved in lipid metabolism. For example, the genes for ApoA-II, ApoA-IV, Apo-B, ApoC-II, and ApoCIII are all regulated by HNF- $4 \alpha$. It has been reported that the serum concentrations of triglycerides as well as apolipoproteins AII and CIII were reduced in some patients with HNF-4 $\alpha$ diabetes [35].

T130I is a rare missense mutation that affects a conserved amino acid in a DNA-binding domain. This mutation can be found in the general population $(0-5 \%)$, so it does not cause MODY alone. However, we recently found that this missense mutation is associated with late-onset type 2 diabetes mellitus in Japanese subjects [36]. Functional analysis suggested that it acts as a loss-of-function mutation in hepatocytes. Thus, the T130I mutation of HNF- $4 \alpha$ may be a genetic risk factor for diabetes and may predispose to type 2 diabetes.

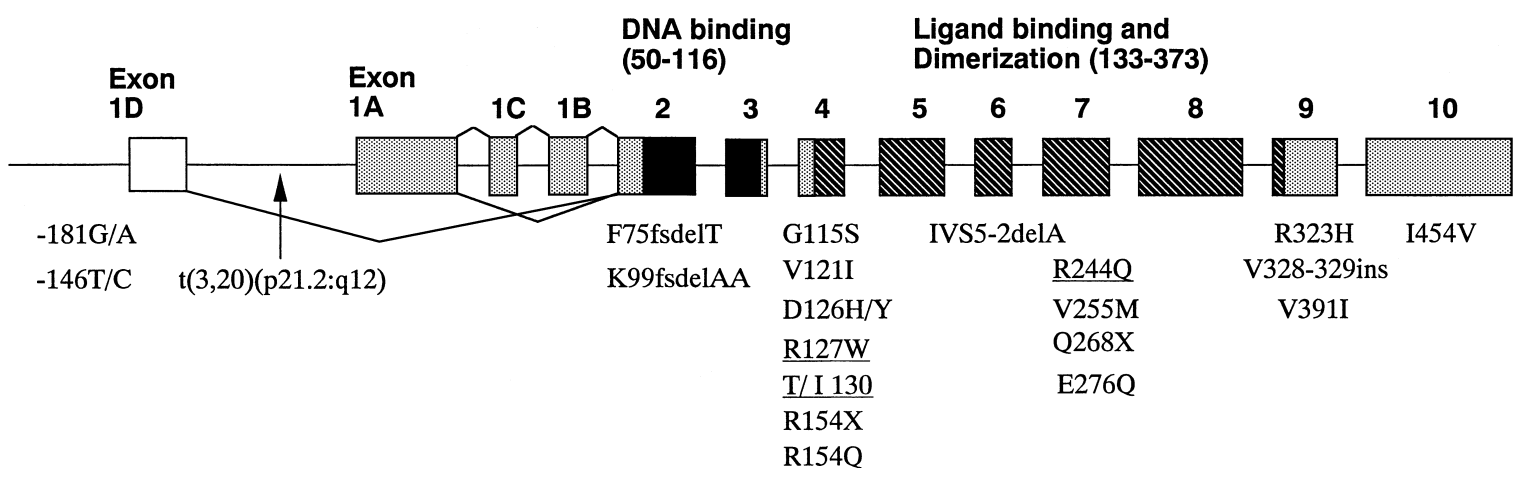

Fig. 2. Mutations and polymorphisms in the HNF-4 $\alpha$ gene. Mutations found in Japanese subjects with diabetes are underlined. 


\section{Role of HNF-4 $\alpha$ in pancreatic $\beta$-cells}

The basic clinical characteristic of HNF- $4 \alpha$ diabetes is impaired insulin secretion from pancreatic $\beta$-cells, but HNF- $4 \alpha$ null mice suffer embryonic death that prevents further analysis of HNF- $4 \alpha$ function in their $\beta$-cells [37]. Overexpression of a dominant negative HNF- $4 \alpha$ mutant in INS-1 cells leads to the reduced expression of the GLUT2, PKL, aldolase B, and OGDH E1 genes, which are also targets of HNF-1 $\alpha$ [38]. The similarity of the genes regulated by HNF-1 $\alpha$ and HNF- $4 \alpha$ might be due to the fact that HNF- $4 \alpha$ is a downstream regulator of HNF- $1 \alpha$ in pancreatic $\beta$ cells. Phosphoenol pyruvate carboxykinase (PEPCK), which is a key enzyme of gluconeogenesis, is an important target of HNF-4 $\alpha$ in the liver [39]. It was reported that liver-specific HNF-4 $\alpha$ knockout mice exhibit hepatomegaly along with reduced serum cholesterol and triglyceride levels and an increase of serum bile acids [40], but there have been no reports about pancreatic $\beta$-cell-specific HNF-4 $\alpha$ knockout mice.

\section{HNF-1 $\beta$ diabetes}

HNF-1 $\beta$ is another homeodomain-containing transcription factor. HNF-1 $\beta$ functions as a homodimer or as a heterodimer with HNF-1 $\alpha$. There is a high level of HNF-1 $\beta$ expression in the kidneys, but it is also found in the pancreas, liver, stomach, and lung. HNF$1 \beta$ regulates the expression of HNF- $4 \alpha 1$ and HNF- $1 \alpha$ in embryoid bodies [41], but the importance of such an action in pancreatic $\beta$-cells remains to be clarified. HNF-1 $\beta$ diabetes is also characterized by impaired insulin secretion. Interestingly, the clinical phenotype of HNF-1 $\beta$ diabetes is not confined to MODY, but also features progressive nondiabetic renal dysfunction $[3,42]$. The renal phenotype varies between families, but kidney cysts are a common feature of the disease. Solitary functioning kidney, renal dysplasia, and glomerulocystic kidney disease have been reported in subjects with HNF-1 $\beta$ mutations. Female subjects with HNF-1 $\beta$ mutations occasionally have genital malformations. Fig. 3 shows a list of mutations/polymorphisms of the HNF-1 $\beta$ gene. $\mathrm{N} 228 \mathrm{~K}$ is a relatively common polymorphism found in Pima Indians and the A241T, G492S, and S465R mutations might be rare polymorphisms. We found the S36F mutation in a Japanese MODY family and functional analysis showed that it was a gain-of-function mutation [43]. It has been reported that overexpression of wild-type HNF-1 $\beta$ in Xenopus embryos leads to impaired development of the pronephros [44].

\section{The HNF network in pancreatic $\beta$-cells}

As described above, the transcriptional hierarchy of HNF in pancreatic $\beta$-cells differs from that in the liver. Fig. 4 shows a summary of the HNF network in pancreatic $\beta$-cells. Although HNF-1 $\alpha$ expression is strictly restricted by HNF- $4 \alpha$ in hepatocytes, HNF- $1 \alpha$ mainly acts as an upstream regulator in pancreatic $\beta$-cells. CREB-binding protein (CBP) and thyroid hormone receptor interacting protein 3 (Trip3) interact with HNF- $4 \alpha$ and augment its transactivation $[45,46]$, while small heterodimer partner (SHP) functions as a co-repressor of HNF-4 $\alpha$. SHP gene expression might, in turn, be regulated by HNF-4 $\alpha$ [47]. SHP interacts with several nuclear receptors and generally represses their functions. Mutations of the SHP gene in humans are associated with mild obesity and insulin

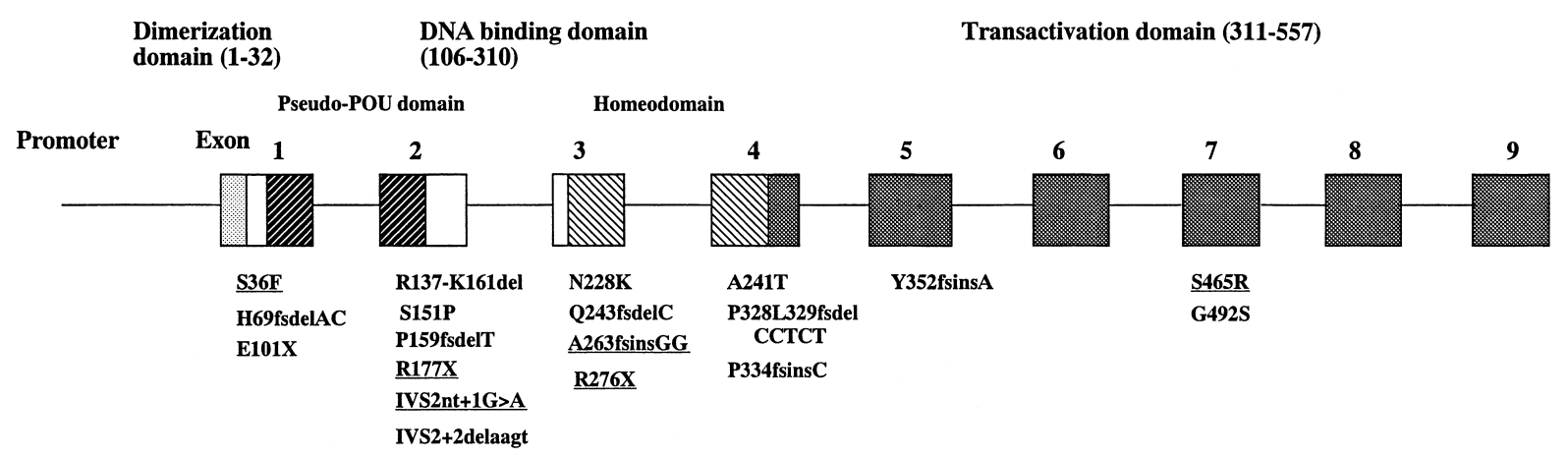

Fig. 3. Mutations and polymorphisms in the HNF-1 $\beta$ gene. Mutations found in Japanese subjects with diabetes are underlined. 


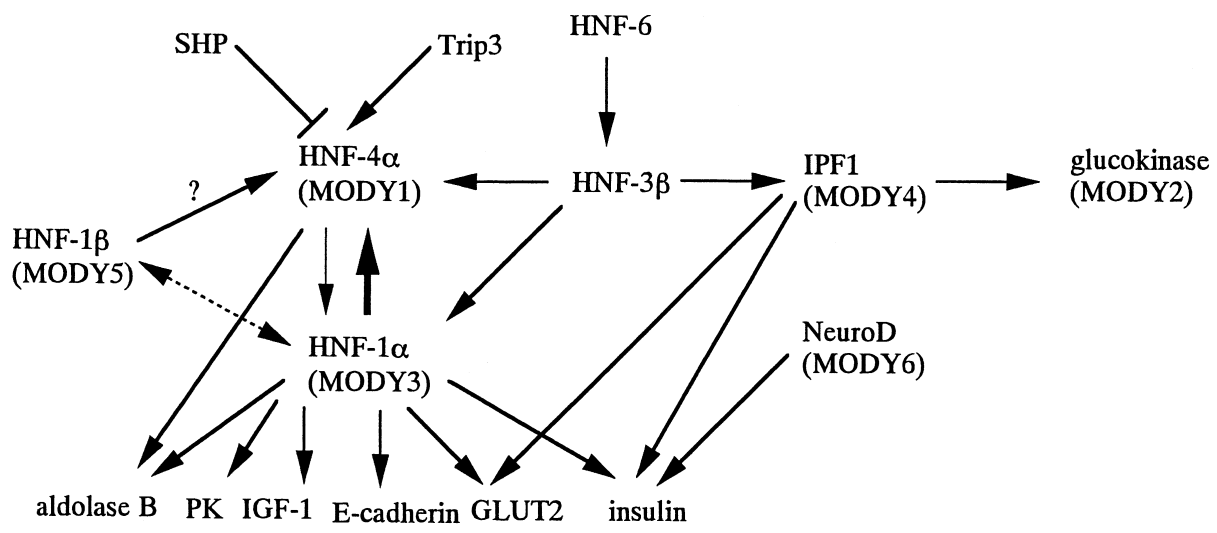

Fig. 4. HNF network in pancreatic $\beta$-cells. HNF- $4 \alpha$ expression is mainly regulated by HNF-1 $\alpha$ in pancreatic $\beta$-cells. HNF-1 $\beta$ functions as a homodimer or as a heterodimer with HNF-1 $\alpha$. SHP inhibits the function of HNF-4 $\alpha$. Trip3 augments the function of HNF- $4 \alpha$.

resistance [48]. We have shown that SHP is a co-activator of peroxisome proliferator-activated receptor $\gamma(\operatorname{PPAR} \gamma)$ and that impaired activation of PPAR $\gamma$ due to defects of SHP might be involved in the insulin resistance observed in persons with SHP gene mutations [49]. HNF- $3 \beta$ is expressed in pancreatic islets, and has been suggested to act as the upstream transactivator of HNF- $1 \alpha$, HNF- $4 \alpha$, and IPF-1 in the transcriptional hierarchy. Although mutations of the HNF-3 $\beta$ gene are not a common cause of MODY, we have found a weak loss-of-function mutation (A86T) of this gene in association with late-onset type 2 diabetes [50]. Thus, weak mutations of the HNF-3 $\beta$ gene might predispose to type 2 diabetes. HNF- 6 transactivates HNF- $3 \beta$ gene expression, but no mutations of the HNF-6 gene have yet been identified in subjects with MODY or type 2 diabetes [51, 52].

\section{Future prospects}

Identification of the HNF genes as diabetogenic genes has led to some degree of understanding as to the importance of these transcription factors in $\beta$-cell function. Recent studies have revealed part of the complex HNF transcription network, but we are still lacking information about the targets of HNFs. Better understanding of the whole network may lead to new therapeutic approaches and agents for MODY. Such knowledge may also help to develop treatment for impaired insulin secretion in the common polygenic form of type 2 diabetes and may even lead to the creation of artificial $\beta$-cells from non- $\beta$-cells such as ES cells.

\section{Acknowledgments}

The author wishes to thank Dr. G. Bell (University of Chicago) for his guidance in the cloning of MODY genes, as well as the members of our laboratories for their contributions to the studies presented here.

\section{References}

1. Yamagata K, Oda N, Kaisaki PJ, Menzel S, Furuta H, Vaxillaire M, Southam L, Cox RD, Lathrop GM, Boriraj VV, Chen X, Cox NJ, Oda Y, Yano H, Le Beau MM, Yamada S, Nishigori H, Takeda J, Fajans SS, Hattersley AT, Iwasaki N, Hansen T, Pedersen O, Polonsky KS, Turner RC, Velho G, Chevre JC, Froguel P, Bell GI (1996) Mutations in the hepatocyte nuclear factor- $1 \alpha$ gene in maturity-onset diabetes of the young (MODY3). Nature 384: 455-458.

2. Yamagata K, Furuta H, Oda N, Kaisaki PJ, Menzel S, Cox NJ, Fajans SS, Signorini S, Stoffel M, Bell GI (1996) Mutations in the hepatocyte nuclear factor$4 \alpha$ gene in maturity-onset diabetes of the young (MODY1). Nature 384: 458-460.

3. Horikawa Y, Iwasaki N, Hara M, Furuta H, Hinokio Y, Cockburn BN, Lindner T, Yamagata K, Ogata M, 
Tomonaga O, Kuroki H, Kasahara T, Iwamoto Y, Bell GI (1997) Mutation in hepatocyte nuclear factor-1 $\beta$ gene (TCF2) associated with MODY. Nat Genet 17: 384-385.

4. Stoffers DA, Ferrer J, Clarke WL, Habener JF (1997) Early-onset type-II diabetes mellitus (MODY4) linked to IPF1. Nat Genet 17: 138-139.

5. Malecki MT, Jhala US, Antonellis A, Fields L, Doria A, Orban T, Saad M, Warram JH, Montminy M, Krolewski AS (1999) Mutations in NEUROD1 are associated with the development of type 2 diabetes mellitus. Nat Genet 323-328.

6. Nammo T, Yamagata K, Hamaoka R, Akiyama TE, Gonzalez FJ, Miyagawa J, Matsuzawa Y (2002) Expression profile of MODY3/HNF-1 $\alpha$ protein in the developing mouse pancreas. Diabetologia 45: 1142 1153.

7. Frayling TM, Evans JC, Bulman MP, Pearson E, Allen L, Owen K, Bingham C, Hannemann M, Shepherd M, Ellard S, Hattersley AT (2001) $\beta$-cell genes and diabetes: molecular and clinical characterization of mutations in transcription factors. Diabetes 50: S94S100.

8. Byrne MM, Sturis J, Menzel S, Yamagata K, Fajans SS, Dronsfield MJ, Bain SC, Hattersley AT, Velho G, Froguel P, Bell GI, Polonsky KS (1996) Altered insulin secretory responses to glucose in diabetic and nondiabetic subjects with mutations in the diabetes mellitus susceptibility gene MODY3 on chromosome 12q. Diabetes 45:1503-1510.

9. Lehto M, Tuomi T, Mahtani MM, Widen E, Forsblom C, Sarelin L, Gullstrom M, Isomaa B, Lehtovirta M, Hyrkko A, Kanninen T, Orho M, Manley S, Turner RC, Brettin T, Kirby A, Thomas J, Duyk G, Lander E, Taskinen MR, Groop L (1997) Characterization of the MODY3 diabetes. J Clin Invest 99: 1-7.

10. Vionnet N, Stoffel M, Takeda J, Yasuda K, Bell GI, Zouali H, Lesage S, Velho G, Iris F, Passa Ph, Froguel $\mathrm{P}$, Cohen D (1992) Nonsense mutation in the glucokinase gene causes early-onset non-insulin-dependent diabetes mellitus. Nature 356: 721-722.

11. Yamagata K, Yang Q, Yamamoto K, Iwahashi H, Miyagawa J, Okita K, Yoshiuchi I, Miyazaki J, Noguchi T, Nakajima H, Namba M, Hanafusa T, Matsuzawa Y (1998) Mutation P291fsinsC in the transcription factor hepatocyte nuclear factor- $1 \alpha$ is dominant negative. Diabetes 47: 1231-1235.

12. Yoshiuchi I, Yamagata K, Yang Q, Iwahashi H, Okita $\mathrm{K}$, Yamamoto K, Oue T, Imagawa A, Hamaguchi T, Yamasaki T, Horikawa Y, Satoh T, Nakajima H, Miyazaki J, Higashiyama S, Miyagawa J, Namba M, Hanafusa T, Matsuzawa Y (1999) Three new mutations in the hepatocyte nuclear factor- $1 \alpha$ gene in Japanese subjects with diabetes mellitus: clinical features and functional characterization. Diabetologia 42: 621-626.
13. Yang Q, Yamagata K, Yamamoto K, Miyagawa J, Takeda J, Iwasaki N, Iwahashi H, Yoshiuchi I, Namba M, Miyazaki J, Hanafusa T, Matsuzawa Y (1999) Structure/function studies of hepatocyte nuclear factor$1 \alpha$, a diabetes-associated transcription factor. Biochem Biophys Res Commun 266: 196-202.

14. Yamada S, Nishigori H, Onda H, Utsugi T, Yanagawa T, Maruyama T, Onigata K, Nagashima K, Nagai R, Morikawa A, Takeuchi T, Takeda J (1997) Identification of mutations in the hepatocyte nuclear factor (HNF)-1 $\alpha$ gene in Japanese subjects with IDDM. Diabetes 46: 1643-1647.

15. Triggs-Raine BL, Kirkpatrick RD, Kelly SL, Norquay LD, Cattini PA, Yamagata K, Hanley AJ, Zinman B, Harris SB, Barrett PH, Hegele RA (2002) HNF-1 $\alpha$ G319S, a transactivation-deficient mutant, is associated with altered dynamics of diabetes onset in an Oji-Cree community. Proc Natl Acad Sci USA 99: 4614-4619.

16. Iwasaki N, Oda N, Ogata M, Hara M, Hinokio Y, Oda Y, Yamagata K, Kanematsu S, Ohgawara H, Omori Y, Bell GI (1997) Mutations in the hepatocyte nuclear factor-1 $\alpha /$ MODY3 gene in Japanese subjects with early- and late-onset NIDDM. Diabetes 46: 1504 1508.

17. Yamada S, Nishigori H, Onda H, Takahashi K, Kitano N, Morikawa A, Takeuchi T, Takeda J (1997) Mutations in the hepatocyte nuclear factor- $1 \alpha$ gene (MODY3) are not a major cause of late-onset NIDDM in Japanese subjects. Diabetes 46: 1512-1513.

18. Urhammer SA, Rasmussen SK, Kaisaki PJ, Oda N, Yamagata K, Moller AM, Fridberg M, Hansen L, Hansen T, Bell GI, Pedersen O (1997) Genetic variation in the hepatocyte nuclear factor- $1 \alpha$ gene in Danish Caucasians with late-onset NIDDM. Diabetologia 40: 473-475.

19. Macfarlane WM, Frayling TM, Ellard S, Evans JC, Allen LI, Bulman MP, Ayres S, Shepherd M, Clark P, Millward A, Demaine A, Wilkin T, Docherty K, Hattersley AT (1999) Missense mutations in the insulin promoter factor-1 gene predispose to type 2 diabetes. J Clin Invest 104: R33-R39.

20. Hani EH, Stoffers DA, Chevre JC, Durand E, Stanojevic V, Dina C, Habener JF, Froguel P (1999) Defective mutations in the insulin promoter factor-1 (IPF-1) gene in late-onset type 2 diabetes mellitus. $J$ Clin Invest 104: R41-R48.

21. Wang H, Maechler P, Hagenfeldt KA, Wollheim CB (1998) Dominant negative suppression of HNF-1 $\alpha$ function results in defective insulin gene transcription and impaired metabolism-secretion coupling in a pancreatic $\beta$-cell line. EMBOJ 17: 6701-6713.

22. Yamagata K, Nammo T, Moriwaki M, Ihara A, Iizuka K, Yang Q, Satoh T, Li M, Uenaka R, Okita K, Iwahashi H, Zhu Q, Cao Y, Imagawa A, Tochino Y, Hanafusa T, Miyagawa J, Matsuzawa Y (2002) Over- 
expression of dominant-negative mutant HNF-1 $\alpha$ in pancreatic $\beta$-cells causes abnormal islet architecture with decreased expression of E-cadherin, reduced $\beta$ cell proliferation and diabetes. Diabetes 51: 114-123.

23. Okita K, Yang Q, Yamagata K, Hangenfeldt KA, Miyagawa J, Kajimoto Y, Nakajima H, Namba M, Wollheim CB, Hanafusa T, Matsuzawa Y (1999) Human insulin gene is a target gene of hepatocyte nuclear factor-1 $\alpha$ (HNF-1 $\alpha)$ and HNF-1 $\beta$. Biochem Biophys Res Commun 263: 566-569.

24. Wang H, Antinozzi PA, Hagenfeldt KA, Maechler P, Wollheim CB (2000) Molecular targets of a human HNF1 $\alpha$ mutation responsible for pancreatic $\beta$-cell dysfunction. EMBO J 19: 4257-4264.

25. Wobser H, Dußmann H, Kogel D, Wang H, Reimertz C, Wollheim CB, Byrne MM, Prehn JH (2002) Dominant-negative suppression of HNF-1 $\alpha$ results in mitochondrial dysfunction, INS-1 cell apoptosis, and Increased sensitivity to ceramide-, but not to high glucose-induced cell death. J Biol Chem 277: 64136421.

26. Yang Q, Yamagata K, Fukui K, Cao Y, Nammo T, Iwahashi $H$, Wang $H$, Matsumura I, Hanafusa $T$, Bucala R, Wollheim CB, Miyagawa J, Matsuzawa Y (2002) Hepatocyte nuclear factor- $1 \alpha$ modulates pancreatic $\beta$-cell growth by regulating the expression of insulin-like growth factor-1 in INS-1 cells. Diabetes 51: 1785-1792.

27. Pontoglio M, Sreenan S, Roe M, Pugh W, Ostrega D, Doyen A, Pick AJ, Baldwin A, Velho G, Froguel P, Levisetti M, Bonner-Weir S, Bell GI, Yaniv M, Polonsky KS (1998) Defective insulin secretion in hepatocyte nuclear factor $1 \alpha$-deficient mice. J Clin Invest 101: 2215-2222.

28. Boj SF, Parrizas M, Maestro MA, Ferrer J (2001) A transcription factor regulatory circuit in differentiated pancreatic cells. Proc Natl Acad Sci USA 98: 1448114486.

29. Parrizas M, Maestro MA, Boj SF, Paniagua A, Casamitjana R, Gomis R, Rivera F, Ferrer J (2001) Hepatic nuclear factor $1-\alpha$ directs nucleosomal hyperacetylation to its tissue-specific transcriptional targets. Mol Cell Biol 21: 3234-3243.

30. Dhe-Paganon S, Duda K, Iwamoto M, Chi YI, Shoelson SE (2002) Crystal structure of the HNF4 $\alpha$ ligand binding domain in complex with endogenous fatty acid ligand. J Biol Chem 277: 37973-37976.

31. Wisely GB, Miller AB, Davis RG, Thornquest AD Jr, Johnson R, Spitzer T, Sefler A, Shearer B, Moore JT, Miller AB, Willson TM, Williams SP (2002) Hepatocyte nuclear factor 4 is a transcription factor that constitutively binds fatty acids. Structure (Camb) 10: 1225-1234.

32. Thomas H, Jaschkowitz K, Bulman M, Frayling TM, Mitchell SM, Roosen S, Lingott-Frieg A, Tack CJ,
Ellard S, Ryffel GU, Hattersley AT (2001) A distant upstream promoter of the HNF- $4 \alpha$ gene connects the transcription factors involved in maturity-onset diabetes of the young. Hum Mol Genet 10: 2089-2097.

33. Hansen SK, Parrizas M, Jensen ML, Pruhova S, Ek J, Boj SF, Johansen A, Maestro MA, Rivera F, Eiberg H, Andel M, Lebl J, Pedersen O, Ferrer J, Hansen T (2002) Genetic evidence that HNF-1 $\alpha$-dependent transcriptional control of HNF- $4 \alpha$ is essential for human pancreatic $\beta$ cell function. J Clin Invest 110: 827-833.

34. Gragnoli C, Lindner T, Cockburn BN, Kaisaki PJ, Gragnoli F, Marozzi G, Bell GI (1997) Maturity-onset diabetes of the young due to a mutation in the hepatocyte nuclear factor- $4 \alpha$ binding site in the promoter of the hepatocyte nuclear factor-1 $\alpha$ gene. Diabetes 46: 1648-1651.

35. Shih DQ, Dansky HM, Fleisher M, Assmann G, Fajans SS, Stoffel M (2000) Genotype/phenotype relationships in HNF-4alpha/MODY1: haploinsufficiency is associated with reduced apolipoprotein (AII), apolipoprotein (CIII), lipoprotein(a), and triglyceride levels. Diabetes 49: 832-837.

36. Zhu Q, Yamagata K, Miura A, Shihara N, Horikawa Y, Takeda J, Miyagawa J, Matsuzawa Y (2003) T130I mutation in HNF- $4 \alpha$ gene is a loss-of-function mutation in hepatocytes and is associated with late-onset type 2 diabetes in Japanese subjects. Diabetologia 46: 567-573.

37. Chen WS, Manova K, Weinstein DC, Duncan SA, Plump AS, Prezioso VR, Bachvarova RF, Darnell JE Jr (1994) Disruption of the HNF-4 gene, expressed in visceral endoderm, leads to cell death in embryonic ectoderm and impaired gastrulation of mouse embryos. Genes Dev 8: 2466-2477.

38. Wang H, Maechler P, Antinozzi PA, Hagenfeldt KA, Wollheim CB (2000) Hepatocyte nuclear factor 4alpha regulates the expression of pancreatic beta -cell genes implicated in glucose metabolism and nutrient-induced insulin secretion. J Biol Chem 275: 35953-35959.

39. Yoon JC, Puigserver P, Chen G, Donovan J, Wu Z, Rhee J, Adelmant G, Stafford J, Kahn CR, Granner DK, Newgard CB, Spiegelman BM (2001) Control of hepatic gluconeogenesis through the transcriptional coactivator PGC-1. Nature 413: 131-138.

40. Hayhurst GP, Lee YH, Lambert G, Ward JM, Gonzalez FJ (2001) Hepatocyte nuclear factor $4 \alpha$ (nuclear receptor 2A1) is essential for maintenance of hepatic gene expression and lipid homeostasis. Mol Cell Biol 21: 1393-1403.

41. Barbacci E, Reber M, Ott MO, Breillat C, Huetz F, Cereghini S (1999) Variant hepatocyte nuclear factor 1 is required for visceral endoderm specification. Development 126: 4795-4805.

42. Nishigori H, Yamada S, Kohama T, Tomura H, Sho K, Horikawa Y, Bell GI, Takeuchi T, Takeda J (1998) 
Frameshift mutation, A263fsinsGG, in the hepatocyte nuclear factor-1 $\beta$ gene associated with diabetes and renal dysfunction. Diabetes 47: 1354-1355.

43. Yoshiuchi I, Yamagata K, Zhu Q, Tamada I, Takahashi Y, Onigata K, Takeda J, Miyagawa J, Matsuzawa Y (2002) Identification of a gain-of-function mutation in the HNF-1beta gene in a Japanese family with MODY. Diabetologia 45: 154-155.

44. Wild W, Pogge von Strandmann E, Nastos A, Senkel S, Lingott-Frieg A, Bulman M, Bingham C, Ellard S, Hattersley AT, Ryffel GU (2000) The mutated human gene encoding hepatocyte nuclear factor $1 \beta$ inhibits kidney formation in developing Xenopus embryos. Proc Natl Acad Sci USA 97: 4695-4700.

45. Iwahashi H, Yamagata K, Yoshiuchi I, Terasaki J, Yang Q, Fukui K, Ihara A, Zhu Q, Asakura T, Cao Y, Imagawa A, Namba M, Hanafusa T, Miyagawa J, Matsuzawa Y (2002) Thyroid hormone receptor interacting protein 3 (trip3) is a novel coactivator of hepatocyte nuclear factor-4alpha. Diabetes 51: 910-914.

46. Yang Q, Yamagata K, Yamamoto K, Cao Y, Miyagawa J, Fukamizu A, Hanafusa T, Matsuzawa Y (2000) R127W-HNF-4 $\alpha$ is a loss of function mutation but not a rare polymorphism and causes Type II diabetes in a Japanese family with MODY1. Diabetologia 43: 520524.

47. Shih DQ, Screenan S, Munoz KN, Philipson L, Pontoglio M, Yaniv M, Polonsky KS, Stoffel M (2001) Loss of HNF-1alpha function in mice leads to abnormal expression of genes involved in pancreatic islet development and metabolism. Diabetes 50: 24722480 .

48. Nishigori H, Tomura H, Tonooka N, Kanamori M,
Yamada S, Sho K, Inoue I, Kikuchi N, Onigata K, Kojima I, Kohama T, Yamagata K, Yang Q, Matsuzawa Y, Miki T, Seino S, Kim MY, Choi HS, Lee YK, Moore DD, Takeda J (2001) Mutations in the small heterodimer partner gene are associated with mild obesity in Japanese subjects. Proc Natl Acad Sci USA 98: 575-580.

49. Nishizawa H, Yamagata K, Shimomura I, Takahashi M, Kuriyama H, Kishida K, Hotta K, Nagaretani H, Maeda N, Matsuda M, Kihara S, Nakamura T, Nishigori H, Tomura H, Moore DD, Takeda J, Funahashi T, Matsuzawa Y (2002) Small heterodimer partner, an orphan nuclear receptor, augments peroxisome proliferatoractivated receptor $\gamma$ transactivation. $J$ Biol Chem 277: 1586-1592.

50. Zhu Q, Yamagata K, Yu L, Tomura H, Yamada S, Yang Q, Yoshiuchi I, Sumi S, Miyagawa J, Takeda J, Hanafusa T, Matsuzawa Y (2000) Identification of missense mutations in the hepatocyte nuclear factor$3 \beta$ gene in Japanese subjects with late-onset Type II diabetes mellitus. Diabetologia 43: 1197-1200.

51. Zhu Q, Yamagata K, Tsukahara Y, Yang Q, Liu W, Hanafusa T, Miyagawa J, Matsuzawa Y (2001) Mutation screening of the hepatocyte nuclear factor (HNF)6 gene in Japanese subjects with diabetes mellitus. Diabetes Res Clin Pract 52: 171-174.

52. Moller AM, Ek J, Durviaux SM, Urhammer SA, Clausen JO, Eiberg H, Hansen T, Rousseau GG, Lemaigre FP, Pedersen O (1999) Hepatocyte nuclear factor-6: associations between genetic variability and type II diabetes and between genetic variability and estimates of insulin secretion. Diabetologia 42: 1011-1016. 